of these two types of parasites. Helminthic parasites are common from soil where as protozoan parasites are found in the faces and gets contaminated through faeco-oral route only.

In the present study, among the various parasites detected, the most common was G. lamblia $(30.9 \%)$ and Enatmoebahistolytica (5.2\%) the protozoan parasite. This finding was in agreement with previous reports (Ihaboet al, 2011; Raiet $a l)^{25,19}$,. However it was in contrast with other similar studies in Nepal and else where (Raiet al, 1995; Ugaet al, 2004) ${ }^{15,18}$.High prevalence of G. lamblia might be due to consumption of raw fecal contaminated water because of drinking raw water, water sources may be in contact with pig farming, animal farming and poor sewerage system.

Similarly, among the helminthes, hookworm (18.6\%) $\%$ ) was the commonest parasite in the study group, followed by $A$. lumbricoides $(15.5 \%)$ and $H$. nana $(6.2 \%)$ High prevalence of hookworm among the helminthes was in agreement with the previous reports (Raiet al, 1995; Raiet al, 2008) ${ }^{19,20}$. However, this finding was in contrast to most other findings reported earlier in which A. lumbricoides topped the list (Raiet al, 1995; Shakyaet al, 2012) ${ }^{19,1}$. High prevalence of hookworm might be due to open defecation that may cause the contamination of soil with hookworm larva and then farming in the field with bare foot. Low prevalence of A.lumbricoides might be due to intake of anti-helminthic drugs as well as public awareness about parasitic infections.

The prevalence of monoparasitism was higher (76.3\%) than multiparastism $(23.7 \%)$ in the study population. This finding was in agreement with the previous reports ( Ugaet al, 2004; Magaret al, 2011) ) $^{1526}$.But higher percentage of multiparasitism has also been reported by Ishiyamaet al $(2001)^{13}$. The higher rate of monoparasitism with $G$. lamblia might be due to the consumption of raw fecal contaminated water.

\section{CONCLUSIONS}

The incidence of intestinal parasitosis is as high as 29\%. The prevalence of parasitic infection was significantly higher among boys (37.9.\%) than girls (21.9\%). Highest infection rate was observed in the children aged between 5 - 10 years (67.0\%). The commonest parasites detected were helminthes (40.2\%). Regular deworming program in association to other preventive measures may help reduce the prevalence.

\section{REFERENCES}

1. Shakya B, Shrestha S, Madhikarmi NL, Adhikari R (2012). Intestinal parasitic infection among school children. J Nepal Health Res Counc 10: 20-3.

2. Agrawal PK, Rai SK, Khanal LK, Ghimire G, Banjara MR, Singh A. Intestinal parasitic infections among patients attending Nepal Medical College Teaching Hospital, Kathmandu, Nepal. Nepal Med Coll J 2012; 14(2): 80-83.

3. Bhandari N, Kausaph V, Neupane GP. Intestinal Parasitic Infection among School Age Children, 2011. J Nepal Res Counc; 9: 30-2.

4. Tiwari BR, Chadhury R, Adhikari N, Jayaswal SK, Poudel TP and Rijal K. Prevalence of Intestinal Parasitic Infections among school children of Dadeldhura District. JHAS, 2013; 3: $14-6$.

5. Aher A, Kulkarni S. Prevalence of Intestinal Parasites in school going children in a rural community. Int $\mathrm{J}$ BioMed Res 2011; 2: 605-7.

6. Shrestha A, KC Narayan, Sharma R. Prevalence of Intestinal ParasitosisAmong School Children in Baglung District of Western Nepal. Kathmandu Univ Med J 2012;37(1): 3-6. http://dx.doi.org/10.3126/kumj.v10i1.6904

7. Forbes BA, Sahm DF and Weissfeld A. Balley and Scott's Diagnostic Microbiology (11th ed). Mosby 1998.

8. Khanal LK, Rai SK, Khanal PR and Ghimire G (2011). Status of intestinal parasitosis among hospital visiting patients in Deukhury Valley, Dang, Nepal. Nepal Med Coll J 13: 100102.

9. Sherchand SP, Joshi DR, Adhikari N, Gurung K, Pant K,Pun $\mathrm{R}$, Shrestha D and Parajuli K. Intestinal Parasitosis among School going children. JHAS 2010;1: 12-5.

10. Oliveira MC, De Silva CV and Costa-Cruz JM (2003). Intestinal parasites and commensals among individuals from a landless camping in the rural area of Uberlandia, Minas Gerais, Brazil. Rev Inst Med Trop Sao Paulo 45: 173-176. http://dx.doi.org/10.1590/S0036-46652003000300011

11. Rai DR, Rai SK, Sharma BK, Ghimire P and Bhatta DR (2005). Factors associated with intestinal parasitic infection among school children in a rural area of Kathmandu Valley, Nepal. Nepal Med Coll J 7: 43-46.

12. Gyawali N, Amatya R and Nepal HP (2009). Intestinal parasitosis in school going children of Dharan municipality, Nepal. J Trop Gastroenterol 30: 145-147.

13. Ishiyama $\mathrm{S}$, Ono $\mathrm{K}$, Rai $\mathrm{CK}$, Rai G, Tsuji H, Sharma AP, Chaudhary DR and Rai SK (2001). Study of enteropathogens and its predisposing factors in a sub-urban public school children in Kathmandu. Nepal Med Coll J 3: 5-9.

14. Rai K, Sherchand JB and Bhatt DR (2004). Study 
MJSBH January-June 2014|Vol 13| Issue 1

of enteropathogens and its predisposing factors in gastroenteritis suspected children attending Kanti Children Hospital, Kathmandu, Nepal. J Nepal Assoc Med Lab Sciences 6: 48-53.

15. Uga S, Rai SK, Kimura K, Ganesh R, Kimura D, Wakasugi M, Miyake Y, Ishiyama S and Rajbhandari TP (2004). Parasites detected from diarrheal stool samples collected in Nepal. Southeast Asian Trop Med Public Health J 35: 19-23.

16. Nuchprayoon S, Siriyasatien P, Kraivichian K, Porksakorn C and Nuchprayoon I (2002). Prevalence of parasitic infection among Thai patients at the king Chultalonkorn Memorial Hospital, Bangkok, Thailand. J Med Assoc Thai 85: 415423.

17. Rai DR, Sharma BK, Ghimire P, Bhatt DR and Rai SK (2003). Status of intestinal protozoan parasitic infection in northern part of Kathmandu, Nepal. Nepalese J Microbiol 1: $16-20$.

18. Rai SK, Bajracharya K, Budhathoki S, Khadka JB, Rai KK, Shrestha MK, Sharma CM, Nakanishi M, Kobo T and Shrestha HG (1995). Status of intestinal parasitosis at TU Teaching Hospital. Inst Med J (Nepal) 17: 134-141.

19. Rai SK, Hirai K, Abe A, Ishiyama S, Rai G, Ono K and Uga $S$ (2002). Intestinal parasitosis among school children in rural hilly area of Dhading District, Nepal. Nepal Med Coll J 4: $54-58$

20. Adhikari N, Rai SK and Singh A (2006). Intestinal parasitic infections among HIV seropositive and high risk group subjects for HIV infection in Nepal. Nepal Med Col J 8: 160-169.

21. Sharma BK, Rai SK, Rai DR and Choudhary DR (2004). Prevalence of intestinal parasitic infestation in school children in the northeastern part of Kathmandu Valley, Nepal. Southeast Asian J Trop Med Public Health 35: 501505 .

22. Ishiyama S, Rai SK, Ono K and Uga S (2003). A small-scale study on intestinal parasitosisin a remote villages in Nepal. Nepal Med Coll J 5: 28 -30.

23. Rai SK and Gurung CK (1986). Intestinal parasitic infection in high school children of Birgunj. Inst Med J (Nepal) 8: $33-38$

24. Sherchand JB, Larsson S and Shrestha MP (1996). Intestinal parasites in children and adults with and without abdominal discomfort from the Kathmandu area of Nepal. J Trop Gastroenterol 17: 15-22.

25. Ihabo HI, Binta Y, Yakubo SE. Asymptomatic Giardiasis and Nutritional status of Children in two local government areas in Kaduna state, Niseria. Sierra Leone J BioMed Res 2011; 3: $157-62$

26. Magar DT, Rai SK, Lekhak B and Rai KR (2011). Study of parasitic infection among children of SukumbasiBasti in Kathmandu Valley. Nepal Med Coll J 13: 7-10. 


\title{
Knowledge and Practice of Solid Waste and Excreta Management at Secondary Schools in Nawalparasi District.
}

\author{
Kashi Palikhe Maskey ${ }^{1}$, Laxmi Lama ${ }^{1}$, Ambu Basnet ${ }^{1}$, Shiva Prakash Dhakal ${ }^{1}$. \\ ${ }^{1}$ Nepalese Army Institute of Health Sciences, College of Nursing, MahankalSthan, New Road, \\ Kathmandu.
}

\begin{abstract}
Introduction: Solid waste and excreta are unwanted materials in environment. It includes garbage (food waste), rubbish (Paper, plastics, and wood, metal, throw-away containers. glass), demolition product (brackets, masonry, and piper) sewage treatment residue (sludge and solids from the coarse screening of the domestic sewage), dead animal manure and other discarded material.

Methods: This cross sectional descriptive study was carried out to find out a study on the practice of solid waste and excreta management among the students of 9-10 grades of Public Secondary schools of Nawalparasi district. For this purpose 168 respondents were provided with semi-structured questionnaire.

Results: A total of 96 percent of the respondent said the class room must be clean but in practice it was found that only 85.71 percent students clean the class room. Majority of the respondent said that they dispose the waste in garbage pit but in practice it was not found so the papers were found to thrown haphazardly. Majority of schools had the facility of the dumping site but they were found to adopt bad practice of solid waste management the dumping site was not well managed. The students were found to have knowledge on solid waste and excreta management but they were only the sources of the solid waste in the school.

Conclusions: There is a need to raise the awareness about the management of the solid waste among students, teaching and non-teaching staffs of the school. Many teachers and students were the sources of the solid waste.

Keywords: solid waste; waste disposal; composting; dumping.
\end{abstract}

\section{INTRODUCTION}

Solid waste is one of the most significant causes of soil pollution, it has important implication for public health, and large quantities of solid wastes are added to the soil each year because of human activities ${ }^{1}$. It is reported that the daily waste generations of 400,000 people in Kathmandu and Lalitpur town were 160 tons $^{2,3}$.

Every school needs to be clean and attractive, it is not only benefit of the teachers and people but also to set a good example of community ${ }^{4}$. Without health, beauty and refreshing environment which pleases the soul the intellectual forces of teachers and people will fail to function their best and the ultimate moral benefit to their nature will be reduced great deal ${ }^{5}$.

For the healthful school environment location of school, ventilation, water supply, toilet, urinal, and solid waste management are necessary. Solid waste management is one of the most important parts of the school for environment because school is the dense populated area; there are different kinds of sports, kinds of people and there are many problems of solid waste, this study was conducted to study the problem of solid waste and their management in schools.

\section{Correspondence:}

Kashi Palikhe Maskey

Nepalese Army Institute of Health Sciences, College of Nursing.

Email:kashimaskey@hotmail.com 


\section{METHODS}

This cross sectional descriptive study was carried out to find out the knowledge on Solid Waste and Excreta Management among the students of 9-10 grades of Public Secondary schools of Nawalparasi district. For this purpose 168 respondents were interviewed with semi-structured questionnaires and observation checklist.

Sampling Procedure and Sample size was taken out of the total 72 government secondary schools located in Nawalparasi district; researcher purposively selected only 7 schools these schools had 1120 students studying in grade 9 and 10 . Researcher selected $15 \%$ of the students randomly as the sample size for the study. Which were 168 students from all the seven schools, which in further equally dividing for the selected 7 schools such that there were 24 students from grade 9 and 10 as the respondents for every selected school.

The questionnaire was having both open and close questions. The research also used observation checklist in order to overview the condition of the solid waste management and availability of facilities. In this way researcher collected data to get information of solid waste and excreta management in public secondary schools of Nawalparasi district. The questionnaire was filled by the respondent themselves. Before the questionnaires were distributed to the students and teachers they were explained about the questions in detail.

\section{RESULTS}

A total of $94.64 \%$ of respondents said they had dumping site and 5.36\% said they don't had it. The data obtained shows the satisfactory presence of dumping site in the study area. To make assured of the data obtained and the reality the observation checklist was also filled, and it was found that there was presence of dumping site in every schools.

A total of $91.07 \%$ solid waste was produced by students, $2.38 \%$ by teachers, $4.16 \%$ by library and $2.39 \%$ by canteen. The findings indicate that the major source of solid waste were students and their activities.

Total $83.34 \%$ respondents says that paper are the waste produce in the school followed by $11.98 \%$ plastics as the waste produce and other were $4.76 \%$. The amount of bio -degradable solid waste was found to be more than that of non-degradable.Out of 168 respondents $96.42 \%$ had the knowledge about solid waste and only $3.58 \%$ percent of the respondents did not have knowledge about solid waste. A total of $96 \%$ of students said the classroom should be clean where as $4 \%$ percent students said that they don't need the classroom to be clean. This reflects that majority of students were clear about the sanitation of their class room.

A total of $95 \%$ of the students have knowledge about proper management of garbage and only $5 \%$ respondent does not have opinion to manage the garbage.Students possess knowledge on the place of garbage disposal on dustbin were 146 . Total $89.8 \%$ percent have knowledge on facility provided by the school for garbage pit only $10 \%$ of students have no idea about the garbage pit.

Only $17.64 \%$ of the school disposed their waste product on open field, $70.58 \%$ the school's dispose their waste product on the back side of school and $11.76 \%$ percent of the school disposed their waste product anywhere.

Total $85.71 \%$ of students they clean the class, followed by $5.95 \%$ by peon and by both the students and peon was $8.33 \%$.

Majority (65) of the schools were converting the solid waste into the compost and still almost the half of the school had not yet adopted the compost making process, they just dump(59) it. Only very few schools (44) had adopted the incineration process. The respondent saying that the removal of the solid waste from their school was done on the regular basic were $85.70 \%$, followed by saying some times were $11.30 \%$ and saying never this kind of activity was done in the school were $2.97 \%$.

Students facing bad smell were $42.86 \%$, followed by $35.72 \%$ of accident, $14.28 \%$ of air pollution and $7.14 \%$ of mental tension.Students get pierce by the nail were $35 \%$, followed by $30 \%$ of glass and entangled $25 \%$ and slippery $10 \%$.

\section{DISCUSSION}

The study of solid waste management is important because the solid wastes are found to be developing as the serious problems everywhere. This study "Knowledge and Practice of Solid Waste and Excreta Management at secondary school in Nawalparasi district" is concerned with the practices adopted by the school family for the management of solid waste in the 